\title{
MANIFESTATION OF PEOPLE'S PARTICIPATION IN THE EXISTING LOCAL GOVERNMENT ACTS IN BANGLADESH
}

\author{
Abu Hossain Muhammad Ahsan ${ }^{1}$ \\ Dewan Nusrat Jahan ${ }^{2}$
}

\begin{abstract}
Whether it is agenda setting, policy formulation or implementation, people's participation at all levels of policy process, decision-making and service delivery has become the prime prerequisite in the prevailing development paradigm. Although in practice there remains huge argument regarding people's effective involvement in the development process due to unwillingness of the supply side and inefficiency, political ignorance of the demand end, it is an undeniable fact that the government of Bangladesh in the recent past has enacted laws for all levels of local government bodies with especial focus given on the people's participation in different phases of development process. This study aims at reconnaissance of the degree of rights and opportunity given to the general people to participate in the development process presented in the existing Local Government Acts, both in rural and urban local government tiers. The study mainly focuses on the secondary sources, exclusively on the existing Local Government Acts and ordinances. The study finds that all acts have significantly included the opportunities for local people to participate in the decision-making process. It is interesting to say that the lower the tier of local government, the higher opportunity to participate in decision making process.
\end{abstract}

Keywords: People's Participation, Local Government Acts, Bangladesh, Decision Making Process, Union Parishad, Paurashava

\section{Introduction}

The importance of local government was felt significant ever since the complexity and intensity of workload increased in the administrative state or central level administration. Local government is a global phenomenon that

\footnotetext{
1 Abu Hossain Muhammad Ahsan is Associate Professor, Department of Public Administration, University of Dhaka, Bangladesh. Email: abuhmahsan@du.ac.bd [Corresponding Author]

2 Dewan Nusrat Jahan is Assistant Professor, Department of Public Administration, Jagannath University, Bangladesh. Email: nusrat.nila@yahoo.com
}

Social Science Review [The Dhaka University Studies, Part-D], Vol. 38, No. 1, June 2021 DOI: https://doi.org/10.3329/ssr.v38i1.56521 
operates from the grassroots level to the district level of any country. Local government system widely varies from country to country depending on country's administrative system; unitary or federal. As a unitary state Bangladesh has also got a local government system operating at the grassroots level nearest to the local inhabitants. Bangladesh got its' independence and sovereignty in 1971 and the country became successful in adopting the constitution within just one year of independence. In this newly adopted constitution, the local government got a significant status through the provisions of democratically elected governance system, a mechanism of service delivery, a quasi-judicial body for local petty arbitration (only at the level of Union Parishad) and a development entity (Ahmed, 2016). Constitutionally Bangladesh is a people's republic. Along with securing the fundamental human rights and freedom of the people, the constitution of Bangladesh has also asserted the effective participation of people at all tiers of local government through the elected representatives (Government of Bangladesh [GoB], 2016).

Since local government in Bangladesh is a democratic institution (as elected by the respective voters) that can ensure effective participation of people in expressing opinions regarding policies as well as implementation of the central or local government agenda (Rahaman \& Hasan, 2014). In reality, from regime to regime the local government of Bangladesh has experienced several changes through the amendments of the Local Government Acts and Ordinances for the protection of the sheer interest of the party or person in power rather than greater interest of the local people (Mallick, 2004), for instance, introduction of Gram Sarker, making respective MP as the advisor of Upazila Parishad, etc. Some of these strategies addressed reduced power and opportunity at the grassroots and some significantly introduced the opportunity of effective participation of local people at the development process and practice. However, it has been studied that the current government has given consummate prominence on people's participation in the decision-making process at the grassroots through amendments of Local Government Acts. Hence, the main objective of this study is to explore the opportunity and extent of people's participation prevalent in the existing Local Government Acts in Bangladesh. 


\section{Literature Review}

The studies on local government have been very popular among the academicians, especially from the background of Public Administration, Political Science and Development Administration/Economics over the last four decades in Bangladesh. There have been several studies conducted, mostly by the academicians, development agencies and the ministry itself, on the people's participation in the governance of local bodies in Bangladesh. It has been observed and studied that most of these studies or papers completely focused on the lowest tier of rural local government; Union Parishad, rather than other rural and urban local government units which are Upazila Parishad, Zila Parishad, Paurashava and City Corporation.

Razzaque (2014) identified some of the good practices on people's participation in the decision-making phase and evaluation of development planning through the mechanism of Ward Meetings, Ward Committee and Open Budget Meeting (Local Government (Union Parishad) Act, 2009) in her study. The good practices identified by the author demonstrate effective participation of local people in terms of the principles of inclusion, effective participation, i.e., addressing voices of the victims or beneficiaries, taking suggestions from the bottom, inclusion of local people in different committees, etc. She further argued that local people are more interested to participate in the decision-making meetings, but they were found quite reluctant in case of participation in the implementation or monitoring of development activities. However, she also suggested introducing legal framework to augment effective participation of the local people and at the same time ensuring cooperative, congenial socio-cultural-political environment during development process for the effective participation of people.

A disagreement can be found in the study conducted by Mohammad (2010) who also studied on the participation of local people in the Ward Shava at the Union Parishad (Act, 2009) level where he investigated a poor level of participation of local people in the preparation of development projects and schemes whereas the socio-economic and political elites of the territory being privileged to contribute to the decision-making processes. He also argued that the political intervention, self-interest of the elected representatives, lack of dissemination of information etc. restrain local people from effective participation. Uddin (2019) analysed different avenues of ensuring people's participation at the Union Parishad level namely Open Budget, Ward Meeting, Standing Committees, Village Court, 
Election etc. He suggests that participation in the decision-making process empowers the participants and lack of empowerment at this field hindrances effective participation at the Union Parishad level in Bangladesh.

Haque (2009) mainly focused on the Standing Committees of UP where he argued that the provision of Standing Committees at the Union Parishad is a medium of ensuring people's participation. He explored the non-functionality of committees and procedural lacking as the responsible factors for the limited access of people to the decision making of Standing Committees. Sowdagar (2013) identified unsatisfactory level of involvement of rural peasants in the decision making and implementation process of the development activities taken by Upazila Parishad. He argued that the poor economic condition and lack of political affiliation of the farmers; reluctance of the Upazila Parishad Chairman in involving people having opposite political ideology; lack of agro based micro planning etc. are hindering the participation of local people. Chowdhury (2017) argued that the Union Parishad Act, 2009 provides the scope of people's participation in planning or budgeting of Union Parishad. He explored different committees, Ward Shava as well as Open Budget where the local people can play role in decision making.

It has been observed that there have been several studies conducted on the issues of people's participation in the development process initiated by different local government bodies but most of the studies mainly focus on the lowest tier of rural local government unit, i.e., Union Parishad, in most studies the other rural local government units and the urban local government unit's interventions to involve local people have been overlooked. The present study aims at exploring the manifestation and magnitude of people's participation prevalent in the Local Government Acts; for all rural and urban local government units. This study will not only identify the scope of people's participation in all the Local Government Acts, both rural and urban local government units, but also will help researchers identify gaps between the provisions of the acts and the implementing practice in the ground reality. After identification of the scope of people's participation it would help researchers conduct further studies on the efficacy of people's participation in different levels of local government. The scope of this present study is concentrated only in the identification of the opportunities of people's participation at all levels which is missing in other studies. This study, at this stage, will not focus on the existing practice of these mechanisms of people's participation. 


\section{Methodology}

The study exclusively applied secondary sources of data collection method. Since the focus of the study is to see the contents of Local Government Acts; the authors primarily collected all the concerned acts which are the main element of analysis under this study. Relevant books, articles, donor agency reports, research reports have been collected to supplement study findings and to see what other agencies or individuals worked on. Moreover, the website of Ministry of Local Government, Rural Development and Co-operatives (LGRD \& C) is regarded as an important source of data in writing this paper.

\section{Local Government in Bangladesh: Legal Framework}

There have been some unwavering directions and concrete provisions in the constitution of Bangladesh with reference to the guiding principles, composition, and functions of local government. The constitution has been the supreme law practiced within the country and suggests basic principles or guidelines for all the Acts passed in the parliament, in accordance several Local Government Acts been passed.

Article 59 and 60 of the Constitution of the People's Republic of Bangladesh emphasize the representation principles of local government bodies so as its functions suggesting there should be local government bodies at all the levels of administrative units and these local government units will be run by the elected representatives. The articles also suggest that there should be Acts for the local government bodies which will be passed following the principles of the constitution. The functions that the local government bodies perform would include administrative works and public affairs, maintaining law and order situation of the given territory, formulation and execution of plans, projects and schemes and finally financial and economic activities, such as, imposing taxes, preparing budget and annual plan, maintaining funds and assets $(\mathrm{GoB}$, 2016).Table 1 shows the traditional classification of the local government units in Bangladesh and their respective Acts. 
Table-1: Classification of local government units and respective Acts.

\begin{tabular}{|c|c|c|}
\hline Classification & $\begin{array}{c}\text { Local Government } \\
\text { Bodies } \\
\text { (Lowest to highest) } \\
\end{array}$ & $\begin{array}{c}\text { Acts passed for respective local } \\
\text { government unit }\end{array}$ \\
\hline \multirow{3}{*}{$\begin{array}{l}\text { Rural Local } \\
\text { Government }\end{array}$} & Union Parishad & $\begin{array}{l}\text { The Local Government (Union } \\
\text { Parishad) Act, } 2009 .\end{array}$ \\
\hline & Upazila Parishad & $\begin{array}{l}\text { The Upazila Parishad Act, } 1998 . \\
\text { The Upazila Parishad (Reintroduction } \\
\text { of the Repealed Act and Amendment) } \\
\text { Act, } \\
\text { The Upazila Parishad (Amendment) } \\
\text { Act, 2011. }\end{array}$ \\
\hline & Zila Parishad & $\begin{array}{l}\text { The Zila Parishad Act, } 2000 . \\
\text { The Zila Parishad (Amendment) Act, } \\
2016\end{array}$ \\
\hline \multirow{2}{*}{$\begin{array}{l}\text { Urban Local } \\
\text { Government }\end{array}$} & Paurashava & $\begin{array}{l}\text { The Local Government (Paurashava) } \\
\text { Act, } 2009 \text {. }\end{array}$ \\
\hline & City Corporation & $\begin{array}{l}\text { The Local Government (City } \\
\text { Corporation) Act, } 2009 .\end{array}$ \\
\hline
\end{tabular}

Source: Constructed by the authors.

\section{Key Findings}

\section{Manifestation of People's Participation in Union Parishad}

The present Awami League led Government of Bangladesh has passed "The Local Government (Union Parishad) Act, 2009" with a view to ensuring people's participation in the decision-making process of the development schemes as well as ensuring the accountability and transparency of the local government activities (Panday, 2011). According to this Act, each union is constituted of nine wards which would be composed of a chairman and twelve members where each of nine general members would be elected from each ward and the other three more female members for whom three seats (each consisting of three general wards) are exclusively reserved, will also be directly elected. 


\section{People's participation through elections}

As mentioned, all the members of the Union Parishad, a chairman and twelve members are directly elected by the inhabitants of the respective territories; chairman is elected by the voters of the whole union, each general member is elected by the voters of respective ward and each female member is elected by the voters of the respective unit consisting of three wards. In electing the representatives of the Union Parishad, the universal adult franchise is followed (Siddiqui \& Ahmed, 2016). Through the provision of voting or the election to choose representatives, this Act has paved the way for direct participation of local people which they can exercise after five years or as or when Union Parishad is dissolved.

\section{Ward Shava: an avenue for direct participation}

There is provision for Ward Shava in the Union Parishad Act, 2009 which encourages people's direct participation in the decision-making process and review of earlier decisions. This act refers to the establishment of Ward Shava in each ward of a Union, nine ward shavas in nine wards. This act also clearly describes the composition of the Ward Shava, according to this; a Ward Shava is composed of all the voters of a given ward. The elected general member of each ward is the Chairman of a Ward Shava and the elected female member acts as an adviser of that meeting. As per provisions, the meeting has to be organized within the territory of a ward and at least $5 \%$ of the voters of that ward need to be present at each meeting. The meeting of the Ward Shava has to be held at least twice a year and it performs mainly the role of selecting development schemes and reviewing the development activities of a ward. The Chairman of the Ward Shava presents the annual report before the members and informs them about the implementation status of the development projects (Panday, 2011). Other important activities of the Ward Shava include preparation of the project proposal at the Ward level, locally aiding in the implementation of the development projects, helping the collection of information for the adoption of Union Parishad development planning (The Local Government (Union Parishad) Act, 2009).

\section{Open Budget Meeting: Opportunity to provide information and insight}

The Union Parishad Act, 2009 describes the procedure of budget approval where the provision of open budget meeting holds dire significance. The first draft of the annual budget has to be formulated at least 60 days prior to the 
commencement of a fiscal year addressing the prioritized projects and schemes sought at the Ward Shavas. This budget draft has to be finalized through a series of screening and discussion procedure including concerned standing committees, Parishad meeting, etc. One of the major means of screening and evaluation of draft budget is the Open Budget Session/meeting where the draft budget has to be presented for discussion, review, and revision. An open announcement has to be made through miking, circular, memo, etc. for the local people so that they get informed about the meeting, attend it, and provide their valuable opinion and insights about the proposed budget. Only after the evaluation at the standing committees and open budget meeting, the draft budget can be placed at the Parishad meeting for approval at the UP level. After that, the budget is sent to the concerned Upazila Nirbahi Officer (UNO) for the final approval. There is also a provision to present the annual financial statement; total account of annual income and expenditure in the Open Budget Meeting.

\section{People's Participation in Standing Committees}

The $45^{\text {th }}$ clause of the Union Parishad Act, 2009 depicts that a Union Parishad will establish 13 mandatory standing committees and other standing committees, if required, for the proper execution of its (Parishad) functions. The number of the members in each standing committee ranges from five to seven. Each standing committee will be headed by the members of the Union Parishad of which the presidents of at least one third committees would be among the elected female members. The rest of the members of the committee, if needed, can be incorporated from among the inhabitants of the Union especially those who are known to have the ability and capacity to contribute to the subject matters of the concerned standing committees.

\section{Union Development and Coordination Committee (UDCC)}

Besides this, the Ministry of Local Government, Rural Development and Cooperatives promulgated a Paripatra (Circular) in 2011 for the formulation of Union Development Coordination Committee under the clause-95 of the Local Government (Union Parishad) Act, 2009. This circular provides the provisions of the local people of different categories to participate in this committee along with other ex-officio members. The main functions of this coordination committee include formulation, implementation, and coordination of socio-economic development planning of a Union. Apart from elected and ex-officio UP and Upazila level members this committee incorporates representatives from Primary 
and Secondary School Management Committees, NGO level field workers working in that Union, members of social/youth club or association, local businessman, Imam or religious leader and female representatives from the community (Ministry of Local Government, Rural Development and Cooperatives, 2011). It is a sheer initiative by the government to accumulate diversified sentiments and opinions to govern Union Parishad.

\section{Provisions for Co-opting Experts}

This Act also encourages co-opting experts or experienced persons as members in different committees of Union Parishad including Parishad meeting, standing committees. The provision of co-opting experts in the committees and meetings is to make sure that Union Parishad and Standing committees can extract apposite insights, technical knowledge, and socio-economic analysis regarding each decision taken.

\section{Manifestation of People's Participation in Upazila Parishad}

According to this Act, an Upazila Parishad consists of the following representatives among which (a) and (b) categories are directly elected by the voters of that Upazila whereas the (c) and (d) are elected people's representatives coming from Union Parishad and Paurashava under a given Upazila: (a) A Chairman; (b) Two Vice Chairmen; one general Vice Chairman and another is reserved for a female Vice Chairman member; (c) Members, and (d) Women members in the reserved seats.

To form an Upazila Parishad people cast their valuable vote, once in five years unless it is dissolved for certain reasons and elect one Upazila Chairman and two Vice Chairmen. The other members of UZP as being the Chairmen of all the Union Parishads and Mayor of Paurashava under that Upazila are also directly elected at their respective territorial local government bodies. One third of the total positions (Chairman, Vice Chairmen, and Members of UZP all together) will be constituted from among the elected female members. The election mechanism to constitute Upazila Parishad has paved the way to ensure people's direct participation.

Apart from electing people's representatives, the scope of people's participation in the decision making and implementation phase of Upazila Parishad development projects and in other activities is quite insufficient in comparison 
with the lowest tier of local government, Union Parishad. Like UP, it also has to constitute sanding committees, specifically seventeen in number where there is the provision to co-opt expert from the concerned field and experienced persons from the community. Neither of the above acts encourages people's direct participation in the budget making procedure through open meetings or other means but it is said that the drafted budget has to be hung on the notice board for 15 days so that people can get informed and give opinions regarding budget allocation and prioritized development schemes.

\section{Manifestation of People's Participation in Zila Parishad}

Unlike other tiers of rural local government unit, Zila Parishad does not encourage people's direct participation in electing the parishad representatives that include Chairman, fifteen members and five women members from the reserved seats. There is the provision of people's indirect participation through Electoral College comprising of the Mayor and Commissioners of the City Corporation, if any; Chairman and Vice Chairmen of Upazila Parishads, Mayor and Commissioners of Paurashava, Chairmen and Members of the Union Parishads within the concerned district.

In addition to the seven obligatory standing committees the Zila Parishad can form any committee, when deemed essential, for the assistance of ZP and to facilitate the development goals of the Zila Parishad. Any person, according to this act, could be nominated by the parishad from among the inhabitants of the jurisdiction to be the members of those committees.

According to the clause 46 of this Act, the statement of accounts of receipts and expenditures of the Zila Parishad has to be prepared after the closing of each financial year and a copy of this statement has to be placed in the Parishad office for public review. Here people can freely express their objections and provide suggestions, subject to the consideration of the Parishad. One of the strategic tasks of ZP, as per clause 49, is to formulate Five Year Plan and other development plans and it also encourages individuals to provide opinions during the formulation phase and would ask for their suggestions before the implementation. It is the responsibility of the Parishad to introduce appropriate means to inform general people so that they can contribute to the various phases of development plans and projects. 
Table-2: Scope and mode of people's participation in rural local government

\begin{tabular}{|c|c|c|}
\hline LG Units & $\begin{array}{c}\text { Manifestation of } \\
\text { People's Participation } \\
\end{array}$ & Mode of People's Participation \\
\hline \multirow{6}{*}{ 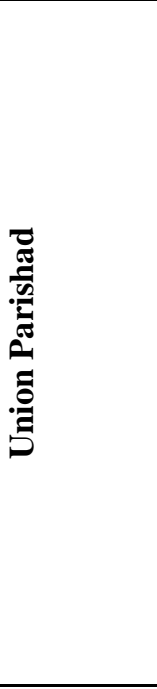 } & Formation of Parishad & Direct Election \\
\hline & Ward Shava & $\begin{array}{l}\text { Minimum } 5 \% \text { of the voters to be present in } \\
\text { each meeting. }\end{array}$ \\
\hline & Open Budget Meeting & $\begin{array}{l}\text { Open for all inhabitants of UP to give } \\
\text { opinion, review, and address revision, if } \\
\text { required. }\end{array}$ \\
\hline & Co-opting members & $\begin{array}{l}\text { An expert, if needed, can be co-opted in } \\
\text { any standing committee }\end{array}$ \\
\hline & Standing Committee & $\begin{array}{l}\text { Local people having ability to contribute } \\
\text { to a certain SC can be included as } \\
\text { members. }\end{array}$ \\
\hline & UDCC & $\begin{array}{l}\text { Representatives of female, youth, } \\
\text { businessman, NGOs, religious leader are } \\
\text { the members. }\end{array}$ \\
\hline \multirow{4}{*}{ 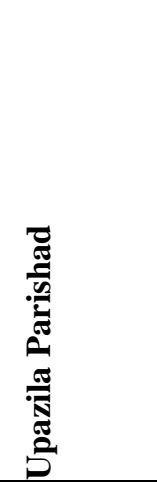 } & Formation of Parishad & $\begin{array}{l}\text { Direct election for } 3 \text { positions, other } \\
\text { members are from the elected } \\
\text { representatives of local government units } \\
\text { under Upazila. }\end{array}$ \\
\hline & Standing Committee & $\begin{array}{l}\text { Local people having ability to contribute } \\
\text { to a certain SC can be included as } \\
\text { members. }\end{array}$ \\
\hline & Co-opting members & $\begin{array}{l}\text { An expert, if needed, can be co-opted in } \\
\text { any standing committee. }\end{array}$ \\
\hline & Budget and Accounts & On the notice board for people's opinion. \\
\hline \multirow{4}{*}{ 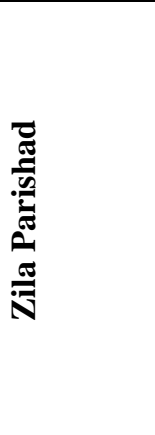 } & Formation of Parishad & $\begin{array}{l}\text { Indirect Participation of people, through } \\
\text { Electoral College. }\end{array}$ \\
\hline & Standing Committee & $\begin{array}{l}\text { Local people having ability to contribute } \\
\text { to a certain SC can be included as } \\
\text { members. }\end{array}$ \\
\hline & Five year and Annual Plan & $\begin{array}{l}\text { No mechanism addressed but provision for } \\
\text { people's opinion regarding plan } \\
\text { formulation. }\end{array}$ \\
\hline & Annual Budget & To be kept at office for open access. \\
\hline
\end{tabular}

Source: Constructed by the authors from existing acts. 


\section{Manifestation of People's Participation in Paurashava}

\section{People's Direct Participation through Election}

According to the Local Government (Paurashava) Act, 2009 a Paurashava consists of a number of elected representatives; a mayor, several councillors where each of them is elected from each of the wards and number of wards that would constitute a Paurashava is determined by the government through a Gazette notification, and female councillors for whom some seats equivalent to one third of the total number of wards are reserved. The Mayor, Councillors, and women Councillors of a Paurashava are elected by direct election based on adult franchise providing opportunity of direct people's participation.

\section{People's Participation in Ward Committees}

This act encourages nether most people's involvement through the establishment of the Ward Committees at all the wards of a Paurashava in which special focus has been given to the participation of the female representatives of the community ensuring at least $40 \%$ of the total number of members. One of the functions of this committee is to organize open meeting so that it can involve the people of the Ward in the development and administrative activities of the Paurashava.

\section{Public Opinion on Paurashava Budget and Annual Accounts}

This act also lays emphasis on public opinion on two of the major activities of a Paurashava; the proposed budget for the subsequent fiscal year and the annual accounts of total income and expenditures of the previous year. Paurashava has to arrange an apparatus at least 30 days prior to the beginning of the fiscal year to receive people's opinion and suggestions on the proposed budget and again the annual report of the accounts of the previous fiscal year has to be kept in an open place for the people to observe, review and their complaints/objections, if any, to be addressed by Paurashava (GoB, 2009).

\section{Scope of Participation in all Committee meetings}

Article 57 is one of the strongest clauses regarding our study which allows an expert or any citizen in the community, by dint of their desire through written application, to take part in any parishad meeting or standing committee meeting 
or any other committee. This act also encourages their participation addressing that their opinions, if deemed appropriate, can be taken by the concerned committee.

\section{Citizens Committee}

As per clause 115, each Paurashava is required to form a Citizens Committee, comprising of not more than 50 local people as members, to render opinion and support for philanthropic and social welfare activities for the community. This committee organizes meeting or dialogue to receive people's opinion regarding Paurashava activities, Tax Assessment, imposing and collection of Tax.

\section{Manifestation of People's Participation in City Corporation}

According to this Act, each City Corporation consists of a mayor, such number of Councillors in the general seats, each from one ward and the number of the wards is determined by the government and in addition one-third of the total wards are reserved exclusively for women Councillors. The mayor, Councillors and women Councillors of a City Corporation are elected by direct election based on adult franchise providing opportunity of people's direct participation in the decisionmaking process.

According to Clause 53, Parishad can co-opt any person if deemed to add value to the decisions of any committee of City Corporation; Parishad, Standing Committee or any other committee. The person would attend the meetings, provide his opinions, review concerned decisions and give suggestions regarding decision and implementation process, though these co-opted persons will not enjoy voting power. Clause 54, on the other hand, allows Parishad to make the meetings open for all subject to the consent of most of the Councillors, unless the meeting is on any secret or classified issues. According to clause 77 of this Act, the annual statement of accounts of receipts and expenditures of the Corporation is to be prepared after the closing of every financial year and a copy of which statement is to be placed in the Corporation office for public opinion and review. City Corporation is supposed to take the objections of the people into consideration and make necessary amendments, if required. 
Table-3: Scope and Mode of People's Participation in Urban Local Government

\begin{tabular}{|c|c|c|}
\hline $\begin{array}{c}\text { LG } \\
\text { Units }\end{array}$ & $\begin{array}{c}\text { Manifestation of People's } \\
\text { Participation }\end{array}$ & Mode of People's Participation \\
\hline \multirow{5}{*}{ 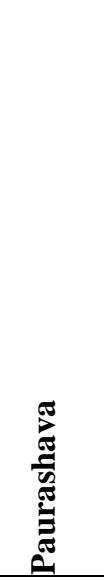 } & Formation of Parishad & Direct Election \\
\hline & Ward Committee & $\begin{array}{l}10 \text { members committee, } 40 \% \text { of them } \\
\text { should be women, organize ward level } \\
\text { open meetings }\end{array}$ \\
\hline & Budget and Accounts & $\begin{array}{l}\text { Parishad needs to arrange mechanism to } \\
\text { get opinion on Budget and Accounts }\end{array}$ \\
\hline & Participation in all Committees & $\begin{array}{l}\text { People can take part in any meeting at all } \\
\text { levels if they apply and it is approved by } \\
\text { majority }\end{array}$ \\
\hline & Citizens Committee & $\begin{array}{l}50 \text { members committee to conduct open } \\
\text { meeting to involve people in decision } \\
\text { making. }\end{array}$ \\
\hline \multirow{3}{*}{ 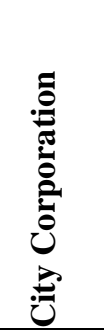 } & Formation of Parishad & Direct Election \\
\hline & $\begin{array}{l}\text { Co-opting experts and allowing } \\
\text { public }\end{array}$ & $\begin{array}{l}\text { Corporation can co-opt any persons in any } \\
\text { committee if deemed necessary, any } \\
\text { person can attend any meeting too if } \\
\text { approved by the majority councillors. }\end{array}$ \\
\hline & $\begin{array}{l}\text { Accounts of total Income and } \\
\text { Expenditures }\end{array}$ & $\begin{array}{l}\text { Corporation needs to arrange mechanism } \\
\text { to get opinion on Budget and Accounts }\end{array}$ \\
\hline
\end{tabular}

Source: Constructed by the authors from existing acts.

\section{Observations and Conclusion}

People's participation for the last quite a few years has been considered one of the crucial issues of good governance and very effective mechanism to solve major social problems. All the social sciences disciplines have significantly emphasized on the importance of the participation of the people at all spheres of the society. Public administration is no exception, focusing illuminative light on people's participation in policy process, governance mechanism, management strategies and styles and even during implementation phase of the development activities. In consistent with this trend the local government acts of different rural and urban local government units in Bangladesh provided opportunities, more or less, to the general people to take part in the decision-making process. 
The foremost mechanism of people's voices to be heard in Bangladesh is the process of direct election where the inhabitants can elect their representatives. This form of government at the bottom where the executive heads of the local government units are directly elected by the voters of the respective territory which ensures people's voices to be heard by the executive head; here all the executive heads of the local government units, except Zila Parishad are directly elected by the voters of the concerned jurisdiction.

The citizens committee is also one of the major mechanisms through which people's voices can heard and participation can be ensured. As per Local Government Acts in Bangladesh we can see that there are opportunities both in rural and urban local government units to form committees, arrange meetings at the people's doorstep. The lowest levels of citizens committees in Bangladesh are the provisions of Ward Shava, Ward Committee and Citizens Committee in Union Parishad and Paurashava. These committees organize meetings to hear from the grassroots people about the priority schemes that local government units take, their opinion regarding decisions, policies, tax, and fees, annual or five-year plan, etc. These committees also inform people about the progress of the development activities.

All the local government bodies after the formation of the Parishad through election have to establish several mandatory standing committees on specific functions which work as the advisory bodies for the Parishad by recommending policy suggestions, addressing strategic decisions, and providing expert opinion regarding each function of the Parishad. In absence of concerned experts (agriculture, fisheries officer, etc.) within the Parishad, all the Local Government Acts of each unit encourage respective unit to co-opt experts and experienced persons in the committees (who are not government officials but experienced in the concerned field, private sector) so that proper review and analysis can be done, and best decisions can be made by the standing committees. Moreover, there is opportunity to incorporate any person of the jurisdiction in the standing committees if committees reckon them having proven ability to contribute to the cause.

It is an undeniable fact that to uphold democracy and ensure democratic practices there is barely any alternative to introducing more mechanisms to ensure effective people's participation in the development process. After analysing all the existing Local Government Acts of all the local government units, it can be 
concluded by saying that the scope of people's participation in the decisionmaking process is much higher at the lowest level of local government units than that of upper levels; more at Union Parishad level than Upazila and Zila Parishad, more at Paurashava than City Corporation.

\section{References}

Ahmed, T. (2016). Bangladesh Reform Agenda for Local Governance. Dhaka: Prothoma Prokashan.

Chowdhury, S (2017). Transparency at the Local Level Planning in Bangladesh: A Study on the Role of Citizen's Charter (CC). Social Science Journal, 21, 57-77. Retrieved from http://www.ru.ac.bd/socialsc/wp-content/uploads/sites/69/2018/08/4.-Shuvra-Chowdhury_PAOk-57-76.pdf (Accessed on September 02, 2019).

Government of Bangladesh.(2016). The Constitution of the People's Republic of Bangladesh. Dhaka, Bangladesh: Department of Legislative and Parliamentary Affairs, Ministry of Law, Justice and Parliamentary Affairs.

Haque, S.T.M. (2009). Challenges of People's Participation at Local Governance: A Case Study on the Standing Committees of Union Parishad in Bangladesh. Nepalese Journal of Public Policy and Governance, 1, 67-85.

Ministry of Local Government, Rural Development and Cooperatives. (2011). Union Development Coordination Committee. Retrieved from http://www.dwatch-bd.org/lgacts.html_(Accessed on September 06, 2019).

Mallick, B. (2004). Local Government: Local People's Institution: A Compilation on Local Government Issue. New Market, Dhaka: A H Development Publishing House.

Mohammad, S. N. (2010). People's Participation in Development Projects at Grass-Root Level: A Case Study of Alampur and Jagannathpur Union Parishad (Masters Thesis, North South University, Bangladesh). Retrieved from http://www.northsouth.edu/newassets/files/ppgresearch/ppg-1st-3rd-batch/119_Noor_Peopl_participation.pdf (Accessed on August 10, 2019).

Panday, P. K. (2011). Local Government System in Bangladesh: How Far is it Decentralized? Lex Localis-Journal of Local Self-Government, 9(3), 205-230.

Rahaman, S. A., \& Hasan, G. S. (2014). Local Government in Bangladesh: Constitutional Provisions and Reality. Metropolitan University Journal, 12, 136-147.

Razzaque, F. (2014). Citizen Participation in Union Parishad's Procurement: A Study on Dhulihor and Nagarghata Union Parishads. RAC Institute of Governance and Development, 23, 1-16.

Siddiqui, K. \& Ahmed, J. (2016). Local Government in Bangladesh. Dhaka: Academic Press and Publishers Library.

Sowdagar, M. U. A. (2013). Challenges of Local Governance: A Study on New Upazila Administration in Bangladesh. Jagannath University Journal of Social Sciences, 1, 56-73.

The Local Government (Union Parishad) Act, 2009 (Act 61 of 2009), (Bgd.).

The Upazila Parishad (Amendment) Act, 2011 (Act 21 of 2011), (Bgd.).

The Zila Parishad Act, 2000 (Act 19 of 2000), (Bgd.).

The Local Government (Paurashava) Act, 2009 (Act 58 of 2009), (Bgd.).

The Local Government (City Corporation) Act, 2009 (Act 60 of 2009), (Bgd.).

Uddin, N. (2019). Empowerment through Participation in Local Governance: The Case of Union Parishad in Bangladesh. Public Administration and Policy, 22(3), 27-45. 